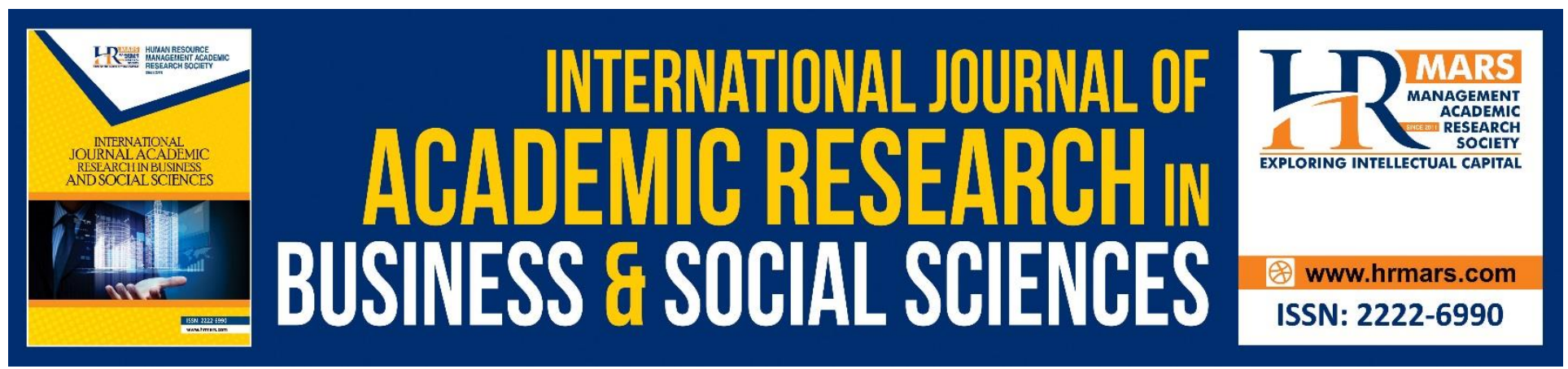

\title{
Relationship between Perceptions of Fitness Facility Service Quality and Future Intentions of Fitness Center Users in Thailand
}

Aminuddin Yusof, Arporn Popa and Soh Kim Geok

To Link this Article: http://dx.doi.org/10.6007/IJARBSS/v8-i7/4424

DOI: $\quad 10.6007 /$ IJARBSS/v8-i7/4424

Received: 02 June 2018, Revised: 19 June 2018, Accepted: 29 June 2018

Published Online: 28 July 2018

In-Text Citation: (Yusof, Popa, \& Geok, 2018)

To Cite this Article: Yusof, A., Popa, A., \& Geok, S. K. (2018). Relationship between Perceptions of Fitness Facility Service Quality and Future Intentions of Fitness Center Users in Thailand. International Journal of Academic Research in Business and Social Sciences, 8(7), 863-871.

Copyright: (c) 2018 The Author(s)

Published by Human Resource Management Academic Research Society (www.hrmars.com)

This article is published under the Creative Commons Attribution (CC BY 4.0) license. Anyone may reproduce, distribute, translate and create derivative works of this article (for both commercial and non-commercial purposes), subject to full attribution to the original publication and authors. The full terms of this license may be seen

at: http://creativecommons.org/licences/by/4.0/legalcode

Vol. 8, No. 7, July 2018, Pg. 863 - 871

http://hrmars.com/index.php/pages/detail/IJARBSS

JOURNAL HOMEPAGE

Full Terms \& Conditions of access and use can be found at http://hrmars.com/index.php/pages/detail/publication-ethics 


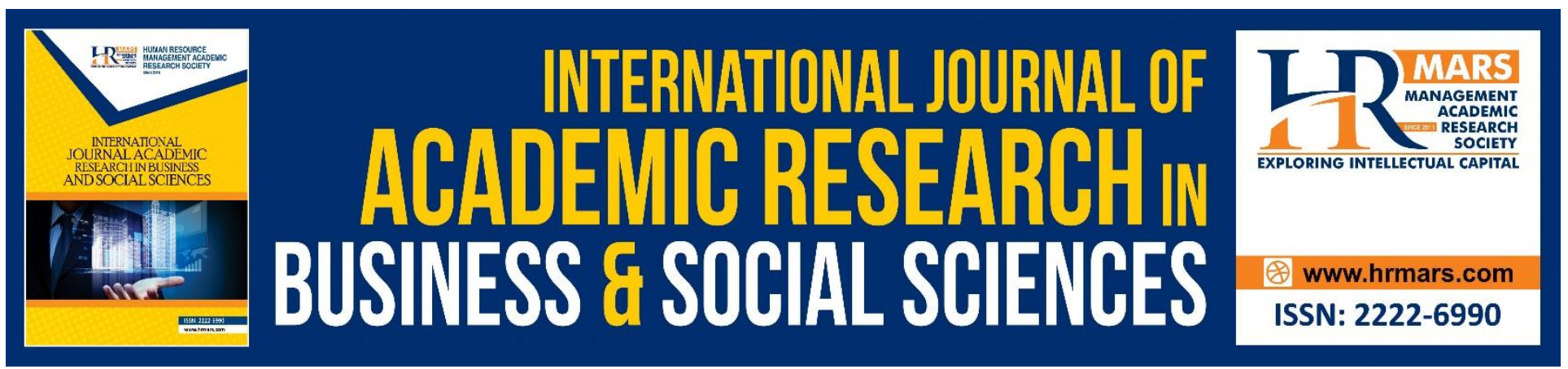

\title{
Relationship between Perceptions of Fitness Facility Service Quality and Future Intentions of Fitness Center Users in Thailand
}

\author{
Aminuddin Yusof ${ }^{1}$, Arporn Popa ${ }^{2}$ and Soh Kim Geok ${ }^{3}$ \\ 1,3 Faculty of Educational Studies, Universiti Putra Malaysia, 43400 UPM Serdang, Selangor, \\ Malaysia \\ ${ }^{2}$ Health \& Sport Science Department, Mahasarakham University, Thailand
}

\begin{abstract}
The purpose of this research was to examine the relationship between perceptions of fitness facility service quality and future intention to use campus fitness center at Mahasarakham university, Thailand. A total of 250 campus recreation fitness center users (males $=189$, females $=61$ ) comprising of students and staff from Mahasarakham University was selected to participate as subjects in the study. The questionnaire consisted of items based on the Likert-scale Service Quality Assessment Scale (SQAS) developed by Lam, Zhang and Jensen (2005). Future intention was measured using two items by Zeithaml et al. (1996): word-of-mouth communications and repurchase intentions. The results showed fitness facility service quality $(ß=.300, p<.05)$ and overall facility service quality $(ß=$ $.278, p<.05)$ contribute significantly towards predicting behavioral intention. This means fitness center users in Mahasarakham University are more likely to renew their membership and recommend the recreation center to other people if they are satisfied with the fitness facility service quality aspects.
\end{abstract}

Keywords: Service Quality, Campus Fitness Center, Behavioural Intentions

\section{Introduction}

Health and fitness is a growing industry worldwide with an annual worth of \$18 billion in the United States. In the United States, there are about 4900 health and fitness clubs with membership totaling about 33.8 million in 1985 (International Health, Racquet and Sport Club Association, 2007). There was a jump of 30-fold in terms of membership in fitness center for a 20-year period from 1982-2002. Changes in consumption patterns as well as increasing consumer awareness about the importance of health and fitness have resulted in a significant increase in health-fitness centers in colleges and universities, work-places, residential buildings, hotels, and resorts. This is due to the demand for health and fitness from customers who wants to exercise either at their place of work or residence. Corporations are investing in fitness centers to reduce the number of staff who are absent from work due to illness as well as reducing the costs of medical insurance. 
INTERNATIONAL JOURNAL OF ACADEMIC RESEARCH IN BUSINESS AND SOCIAL SCIENCES Vol. 8, No. 7, July 2018, E-ISSN: 2222-6990 @ 2018 HRMARS

Providing quality service in a fitness facility is one important element to influence member retention (McDonald \& Howland, 1998; Zeithaml, Berry, \& Parasuraman, 1996). Stum and Thiry (1991) argue that the quality of service in a fitness facility must be met or exceeds the expectations to satisfy users. Service quality in a fitness facility can be defined as the extent of the performance of a fitness center matches or exceeds the what members expect. Service quality is about ensuring customers, both internal and external to achieve their need and desires (Parasuraman, Zeithmal, and Berry, 1985, $1988,1991)$ and representing, producing services or productions in terms of what the customer wants. This can make extra competitive advantage for organisations or companies (Kordi, 2015). Furthermore, service quality which is outstanding is key to any give an organisation to have a competitive edge. This in turn leads to better sales and profit (Szmigin, Canning and Reppel, 2005). If the service provided by an organization is to be better than expected service, customers are more likely to repeat using the service or provide a good word of mouth to others about the organization. On the other hand, customers that experiences bad service will their experience publicly. This will result in discouraging potential customers from using the service at the organization.

Factors that have been found to be related to service quality are the concepts of customer expectations and satisfaction (Bolton \& James, 1991). The literature suggests that service quality comes first before service satisfaction (Brady \& Robertson, 2001; Cronin \& Taylor, 1994; Izogo, 2017). Satisfaction is defined by Oliver (1980) as the gap between service expectations and actual service performance. If a service performance is higher than expected service, then satisfaction is the results. On the other hand, dissatisfaction happens if the actual service performance is lower than what is expected. Since repeat customers in a fitness center are often those who are satisfied with the service, high customer satisfaction is important not only for a better image and reputation but also fewer complaints and getting new customers. In addition, a satisfied fitness center user is more likely to frequent the fitness center as well as participating in other activities at the fitness center. A satisfied user is also more likely to be willing to pay for services even if there is an increase in fees (McAlexander, Kaldenberg, \& Koenig, 1994).

Thus, measurement of service quality is important for a fitness facility to ensure the service quality level is consistently high and to identify the level of member satisfaction. Service quality is determined by post-experience customer research (Robinson, 2003) allowing sports organizations to identify weakness in service quality and introduce quality improvement. Most common type of measurement is done by using a survey given to users to find out whether users are satisfied with the service provided at the fitness facility. In the literature, there are many models to measure service quality. Among the most widely used is the Gap Model (Parasuraman et al. 1985). The Gap Model identify the difference between customers' expectations and their actual experience. The more the actual experience exceeds service expectations, the higher the perception of service quality.

\section{Purpose of Study}

An increasing number of university campuses in Thailand (Senakham, 2010) are establishing campus fitness facilities due to the concern that students are inactive and leading a sedentary lifestyle. In Thailand, the building of campus fitness facilities costs a lot of monetary investment as well as man power to manage the facilities. Additionally, the facilities also require regular maintenance and upkeep. To ensure the fitness facilities are used optimally, it is important for university administrators to determine whether staff and students are actually regularly using the fitness facilities provided by 
INTERNATIONAL JOURNAL OF ACADEMIC RESEARCH IN BUSINESS AND SOCIAL SCIENCES

Vol. 8, No. 7, July 2018, E-ISSN: 2222-6990 @ 2018 HRMARS

the universities. One way is to study the relationship between perceptions of fitness facility service quality and intentions to use the facilities. A study on perceptions of fitness facility service quality is important because it has always been cited as reasons (Lagrosen and Lagrosen, 2007) for continued usage of fitness centers. Thus, the purpose of this research is to examine the relationship between perceptions of fitness facility service quality and future intention to use campus fitness center at Mahasarakham University, Thailand.

The research questions for this study are:

1) What are the perceptions of fitness facility service quality among fitness center users in Mahasarakham University?

2) What are the perceptions of overall facility service quality among fitness center users in Mahasarakham University?

3) What are the behavior intentions among fitness center users in Mahasarakham University?

4) What are the relationship between perceptions of fitness facility service quality and overall facility service quality with fitness center users' intention to use campus fitness centers in Mahasarakham University?

\section{Methodology}

The research design of this study is using surveys to collect data from respondents to examine their perceptions of service quality of campus recreational facilities. Survey questionnaires were distributed to a total of 250 campus recreation fitness center users (males $=189$, females $=61$ ) comprising of students and staff from Mahasarakham University. The subjects were conveniently selected for the study. Table 1 shows the age distribution of the subjects.

Table 1: Age of Subjects

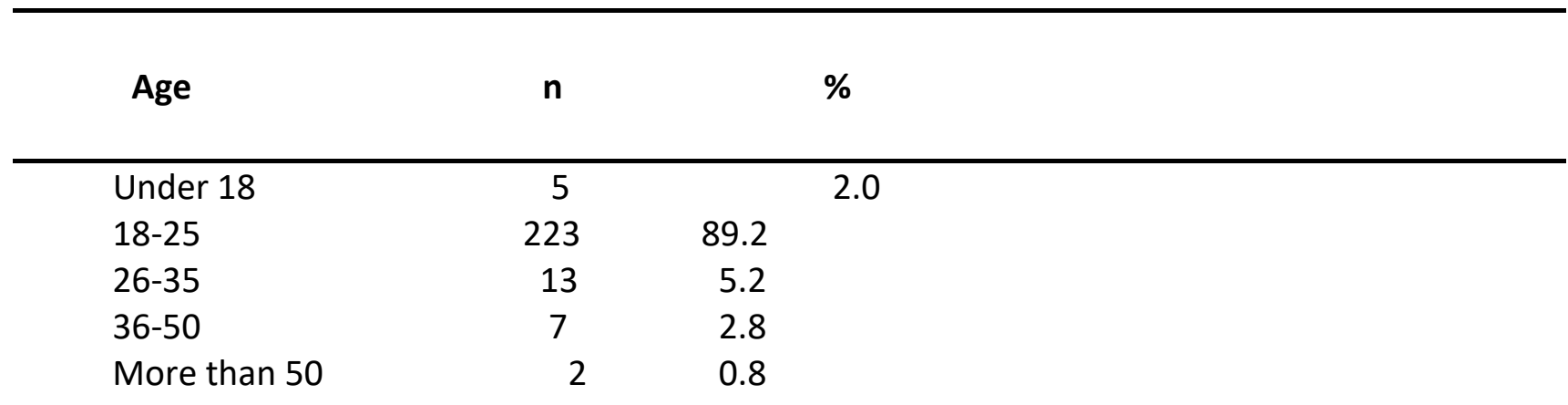

The questionnaire used in the study consists of items based on the Service Quality Assessment Scale (SQAS) modified from the original developed by Lam, Zhang and Jensen (2005) to measure user perceptions of service quality in terms of six dimensions of service quality: staff, programme, locker room, physical facility, workout facility and childcare. The reliability of the 40 items Likert-scale Service Quality Assessment Scale (SQAS) was reported to range from 0.71 to 0.85 . The convergent validity of the measure was reported to be from .62 to .92 (Taghizadeh, Ghorbani and Begnam, 2015). Future intention to use campus fitness at Mahasarakham University, Thailand was measured using two subscales proposed by Zeithaml et al. (1996): word-of-mouth communications (e.g., saying positive things about the facility to others) and repurchase intentions (e.g., membership renewal soon). 
INTERNATIONAL JOURNAL OF ACADEMIC RESEARCH IN BUSINESS AND SOCIAL SCIENCES Vol. 8, No. 7, July 2018, E-ISSN: 2222-6990 @ 2018 HRMARS

Descriptive analyses were used to address research questions regarding the perceptions of fitness facility service quality, overall facility service quality and behaviour intention among fitness center users in Mahasarakham University. Standard multiple regression analysis was used to determine the relationship between perceptions of fitness facility service quality and overall facility service quality and fitness center users' intention to use campus fitness centers in Mahasarakham University Thailand. Multiple regression was used to determine which independent variables are the significant predictors of behaviour intention. It was to research the statistical significance in a regression among the independent variable.

\section{Results}

The first research question examines the perceptions of Mahasarakham University fitness center users about their perceptions of fitness facility service quality. Fitness facility service quality refers to the availability of modern-looking equipment, adequacy of signs and directions, variety of fitness and exercise equipment. It also refers to the availability of workout facility and equipment as well as the overall maintenance of facility and equipment.

Table 2: Perceptions of Fitness Facility Service Quality

N Mean Sd

$249 \quad 3.92$

Table 3 examines the perceptions of overall facility service quality. This is to address research question two. The results show fitness center users in Mahasarakham $(m=37.48)$ have a high perceptions of overall program service quality. The results suggest that the fitness center should be concerned with overall facility service quality such as the convenience of location, hours of operation, availability of parking as well as parking lot safety. It also refers to temperature control, lighting and pleasantness of the facility in terms of environmental friendly.

Table 3: Perceptions of Overall Facility Service Quality

N Mean Sd

$244 \quad 37.48 \quad 8.93$

Research question three examines the behaviour intentions of fitness center users. Behaviour intention is defined as the concept of trying to perform a behavioral goal or a given behavior (Ajzen, 1991). In this study two questions were used to measure behavior intentions. The first asked respondents whether will recommend the recreation center to other people while the second asked respondents whether they have the intention to renew their membership. The results as shown in 
INTERNATIONAL JOURNAL OF ACADEMIC RESEARCH IN BUSINESS AND SOCIAL SCIENCES Vol. 8, No. 7, July 2018, E-ISSN: 2222-6990 @ 2018 HRMARS

Table 4 suggest users at Mahasarakham University $(m=3.73)$ have a moderate level of intention to use the fitness center again in the future.

Table 4: Behaviour Intentions
$\mathbf{N}$
Mean
Sd

250

3.73

.05

Research question 4 seeks to determine the relationship between perceptions of fitness facility service quality and overall facility service quality and fitness center users' intention to use campus fitness centers in Mahasarakham University Thailand. The standard multiple regression analysis (Table 5) shows that fitness facility service quality and overall facility service quality are significant predictors for behavioral intention of fitness center users in Mahasarakham University, $\mathrm{R}^{2}=.365, \mathrm{R}^{2}$ $\operatorname{adj}=. .354, F(4,225)=32.395, p<.05$. Based on this analysis, it shows that fitness facility service quality $(ß=.300, p<.05)$ and overall facility service quality $(ß=.278, p<.05)$ contribute significantly towards predicting behavioral intention. The results showed that fitness center users in Mahasarakham University are more likely to renew their membership and recommend the recreation center to other people if they are satisfied with the fitness facility service quality aspects such as having equipment which are new and modern looking as well as having a variety of different fitness equipment. In addition, fitness center users are also more likely to continue using the facility in the future if the facility is conveniently located as well as having convenient hours of operation, availability of parking as well as parking lot safety.

Table 5: Multiple regression of predictors of intentions for Mahasarakham University Fitness Center Users

\begin{tabular}{lrrrr}
\hline Variable & $\beta$ & $t$ & $p$ \\
\hline & & & & \\
Fitness facility service quality & .300 & 3.675 & $.001^{*}$ & \\
Overall facility service quality & .278 & 3.928 & $.001^{*}$ & \\
\hline
\end{tabular}
$* p<.05$

\section{Discussion}

The purpose of this study was to examine the assumption whether service quality and would result in satisfaction and influence the future behavior intention to frequent a university recreation fitness center. Based on the Customer Satisfaction Theory (Klaus, 1985), service quality is viewed from the perspectives of the customer, with the proposition that a fitness center can be considered as possessing quality if a customer is satisfied with its services. The results of this study supported this proposition and showed that behavior intention of fitness center user at Mahasarakham University could be best predicted by fitness facility service quality and overall facility service quality. Based on the findings, it was found out that, good quality service would influence fitness center users recommending others to use the facilities. In addition, users who are satisfied with the services 
provided are more likely to renew their membership. On the other hand, if fitness center members are not satisfied, they will not renew their membership. Poor service will be more likely be heard by more people than good customer service. Bad service can hamper the fitness center efforts to increase membership and bring in new members. In other words, poor service would result in members telling their experience to others resulting in less new members. Thus, it was concluded that the quality of service provided directly influence behavior intention of fitness center users.

It is important that that customer satisfaction be constantly monitored as this is key to loyalty and retention (Kotler, 2009). The information on customer satisfaction can also be used to evaluate productivity and performance for improving services. According to Faullant et al. (2008), the first impression of service providers plays an important role towards customer retention. If a customer has a positive image towards the service provider, the customer has the tendency not to emphasize on the overall performance evaluation and is willing to provide a further chance if service is not as expected. Thus, it is important to create greater value with new customers and preserve its image. Additionally, to sustain customer satisfaction and loyalty, fitness centers must ensure that the high quality of differentiation and superior quality of service meets satisfied levels of the customers' needs. Since many customers perceive the satisfaction of how programmes are carried out to be related with future satisfaction, fitness center operators should enhance this perception with sincerity and guarantee. Often, customer satisfaction begins to decline when they realised that their needs are not going to be met even before purchasing. Thus, a positive first image is something that fitness center needs to emphasize.

\section{Conclusion and Suggestions}

Administrators at Mahasarakham University could use the findings to attract more students and staff to frequent and use the fitness centers. This would encourage staff and students to lead a much healthier lifestyle and at the same time allow them more freedom to enjoy better work life balance. The current trend of more youngsters seeing the importance of exercise is something positive but according to Ong and Andrews (2011), the practice of active lifestyle among youngsters would stop after they finish high school. It is important for university administrators to encourage the youngsters to continue their healthy lifestyle when they enter the university. This can be done by having a wellmanaged fitness centres.

For Mahasarakham University, retention of members and measuring their loyalty are important. A major source of revenue for a campus fitness center is membership fees and this source of income is directly related with $s$ the ability of the fitness center to retain students and staff as members in the long run. Members' retention is related with loyalty which in turn is related to how they perceived the fitness center service quality. This leads to satisfaction if members are satisfied with the service provided by the provider. The following are some suggestions to retain current members and to attract new ones:

1. Create programs to encourage current users to bring non-users to the fitness centres on special occasions for free.

2. Provide a flexible schedule in terms of the times of operation that can attract new users as well as maintain current users.

3. Conduct activities that can attract attention and increase awareness of the offerings of the fitness center. 
INTERNATIONAL JOURNAL OF ACADEMIC RESEARCH IN BUSINESS AND SOCIAL SCIENCES Vol. 8, No. 7, July 2018, E-ISSN: 2222-6990 @ 2018 HRMARS

4. Create a program aimed at providing good first-time impression for prospective members or a new member who have just signed up.

5. Encourage loyal members to maintain their membership by providing privileges and special benefits.

6. Continuously maintain and upgrade the quality of the equipment at the fitness centre.

\section{References}

Ajzen, I. (1991). The theory of planned behavior. Organizational behavior and human decision processes, 50, 179-211.

Bolton, R. N., \& James, H.D. (1991), A Multi-Stage Model of Customers' Assessments of Service Quality and Value. Journal of Consumer Research, 17 (4), 375-384.

Brady, M. K., \& Robertson, C. J. (2001). Searching for a consensus on the antecedent role of service quality and satisfaction: An exploratory cross-national study. Journal of Business Research, 51(1), 53-60.

Cronin, J \& Taylor, S. (1994). SERVPERF versus SERVQUAL: Reconciling performance-based perceptions_minus_expectations measurement of service quality. Journal of Marketing, 58, 125-131.

Faullant, R., Matzler, K. and Fu“ller, J. (2008). The Impact of Satisfaction and Image of Loyalty: The Case of Alpine Ski Resorts, Managing Service Quality, 18 (2), pp.163-178.

Izogo, E.E. (2017). Customer loyalty in telecom service sector: The role of service quality and customer commitment. The TQM Journal 29(1), 3-20.

International Health, Racquet and Sport Club Association. (2007). ThelHRSA Global

Report on the State of the Health club Industry. Retrieved May 22, 2008, from

http://cms.ihrsa.org/index.cfrn?fuseaction=Page.viewPage\&pageld=19014\&nodelD = 15

Klaus, P. (1985). Quality epiphenomenon: the conceptual understanding of quality in face-to face service encounters", in Czepiel, J.A., Solomon, M.R., Suprenant, C.F. and Gutman, E.G. (Eds), The Service Encounter: Managing Employee Customer Interaction in Service Business, Lexington Books, Lexington, MA.

Kordi, M. (2015). Service quality: any link to customers decision making. Albertiana, 82, 1-6

Kotler, P. (1996). Marketing management-analysis, planning, implementation and control. (9th Ed.). Prentice-Hall Inc.

Lam, E., Zhang, J., \& Jensen, J. (2005). Service quality assessment scale (SQAS): as instrument for evaluating service quality of health fitness clubs. Measurement in Physical Education and Exercise Science, 9:79-111.

Lagrosen, S. \& Lagrosen, Y. (2007). Exploring service quality in the health and fitness industry. Journal of Service Theory and Practice, 17(1), 41-53.

McAlexander, J. H., Kaldenburg, D. O., and Koenig, H. F., 1994. Service Quality Measurement. Journal of Health Care Marketing, 14(3), 34-40.

McDonald, M. A., \& Howland, W. (1998). Health and fitness industry. In L. P.

Masteralexis, C. A. Barr, \& M. A. Hums (Eds.). Principles and Practice of Sport Management, 431-451. Gaithersburg, MD: ASPEN.

Oliver, R. (1980). A cognitive model of the antecedents and consequences of satisfaction decisions. Journal of Marketing Research, 17, 460-469.

Ong, L. T., Andrews, E. and Tan, S.L. (2012). A Study of Customer Retention and Churn Management through Data Mining and Customer Profiling of Malaysian Mobile Users. Proceedings of the 
INTERNATIONAL JOURNAL OF ACADEMIC RESEARCH IN BUSINESS AND SOCIAL SCIENCES

Vol. 8, No. 7, July 2018, E-ISSN: 2222-6990 @ 2018 HRMARS

Academy of World Business Marketing and Management Development (AWBMAMD) Conference, Budapest, Hungary, 5(1), July 2011, pp. 197-210.

Parasuraman, A., Berry, L. L. \& Zeithaml, V. A. (1991). Refinement and reassessment of the SERVQUAL scale. Journal of Retailing, 67(4)

Parasuraman, A., Zeithaml, V. A. \& Berry, L. L. (1988). SERVQUAL: A multiple-item scale for measuring consumer perceptions of service quality. Journal of Retailing, 64(1), 12-40.

Parasuraman, A., Zeithaml, V. A. \& Berry, L. L. (1985). A conceptual model of service quality and its implications for future research. American Marketing Association, 49(4):41-50.

Robinson, L. (2003). The business of sport. In B. Houlihan (Ed.), Sport and society. London: Sage.

Senakham, T. (2010). Customers' expectations of service quality in the Thai University fitness centers in Bangkok metropolitan area, Kingdom of Thailand. Spanish Fort: United States Sports Academy.

Stum, D. L., \& Thiry, A. (1991). Building customer loyalty. Training and Development Journal, 45 (4), 34-36.

Szmigin, I., Canning, L. \& Reppel, A. E. (2005). Online community: enhancing the relationship marketing concept through customer bonding. International Journal of Service Industry Management, 16(5), 480-496

Taghizadeh, F. \& Ghorbani, H. O. (2015). The psychological continuum model: examination of spectators' involvement levels in the football. Sport Science, 8(1), 64-71.

Zeithaml, V., Berry, L. and Parasuraman, A. (1996). The Behavioral Consequences of Service Quality, Journal of Marketing, 60, pp. 31-46.

Zeithaml, V. and Bitner, M. (2000). Services Marketing: Integrating Clients' Focus across Firms. New York: McGraw-Hill. 